\title{
錫含浸法によるリサイクルWC 微粒子を用いた再生超硬合金の物性
}

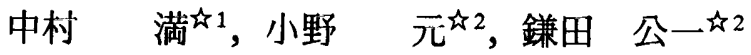 \\ 41 岩手大学工学部, $\bar{T} 020-8551$ 盛岡市上田 4-3-5. \\ ฟ2岩手県工業技術センター，产020-0852 盛岡市飯岡新田 3-35-2.
}

\section{Some Physical Properties of Regeneration Cemented Carbide Using Recycling WC Fine Powder by Tin Impregnation Method}

\author{
Mitsuru Nakamura ${ }^{\text {t1 }}$, Tsukasa Ono ${ }^{\text {2 } 2}$ and Ko-ichi Kamada \\ ${ }^{4}$ Fac. Eng., Iwate University, 4-3-5 Ueda, Morioka 020-8551. \\ '2 Iwate Industrial Research Institute, 3-35-2 Iiokashinden, Morioka 020-0852.
}

Received October 25, 2004

\section{SYNOPSIS}

In this experiment, the development of recycling method at cemented carbide scraps was researched. First, brittle alloy was obtained by tin impregnation method and then WC fine powder was procured after the physical crushing. Thereafter, the sample followed by the processes of reduction treatment, molding and sintering works. Some properties of recycled cemented carbides were investigated. The results summarized as follows; Recycled WC fine powder suffered the surface oxidation. Therefore it was necessary to be done by reduction treatment at $1073 \mathrm{~K}-3.6 \mathrm{ks}$ under hydrogen atmosphere. When sintering condition at $1673 \mathrm{~K}-3.6 \mathrm{ks}$ was treated under vacuum condition, it gained the deflective strength of about $90 \%$, and gained hardness and sintering density about same value compared with commercial alloys. As a result, it was able to recycle only by 7 processes, that is to say, tin impregnation, physical milling, stirring $\mathrm{HCl}$ cleaning, reduction, mixing, molding and sintering works.

KEY WORDS

recycling process, cemented carbides, tin impregnation method, surface oxidation, deflective strength

\section{1 緒 言}

著者らは偂報りにおいて，主として金型及び工具に使用さ れ，その後産業廃棄物として廃棄されている超硬合金(WCCo系)について，その物性値の有益性はもちろんのこと，希 少金属 (W, Co 等)を使用しているため $3 \sim 4$ 万円 $/ \mathrm{Kgf}$ と非常 に高価である，この合金のリサイクル技術を提案した。すな わち, 人体に無害で, 低コストでかつ省エネルギー技術であ る新しいリサイクル法として錫 $(\mathrm{Sn})$ 含漫法 ${ }^{2}$ を提案し，WC とCoを完全に分離する手法から，WC微粉末及びCo-Sn化合 物として回収することにより，市販品と同程度 $(1 \sim 4 \mu \mathrm{m})$ の WC 微粉末を回収する方法を開発したものである.

Fig.1は前報で得られた超硬合金中のWC粉末回収のための リサイクルプロセスを示す.この実験では, Sn 浴の中で超硬 合金を $1323 \mathrm{~K}$ で $7.2 \mathrm{ks}$ 保持することにより，Co と Snの冶金 的反応を利用して $\mathrm{Co}_{3} \mathrm{Sn}_{2}$ ( $\gamma^{\prime}$ 相)を生成し，その後このWCと $\gamma^{\prime}$ 相を $18 \% \mathrm{vol} . \mathrm{HCl}$ 水溶液で摫抖洗浄することにより, WCは 水溶液中に沈殿し, Co-Sn 化合物は $\mathrm{HCl}$ 中に溶解する。ささら に，得られたWC粉末をスタンプミル等により物理的粉砕す

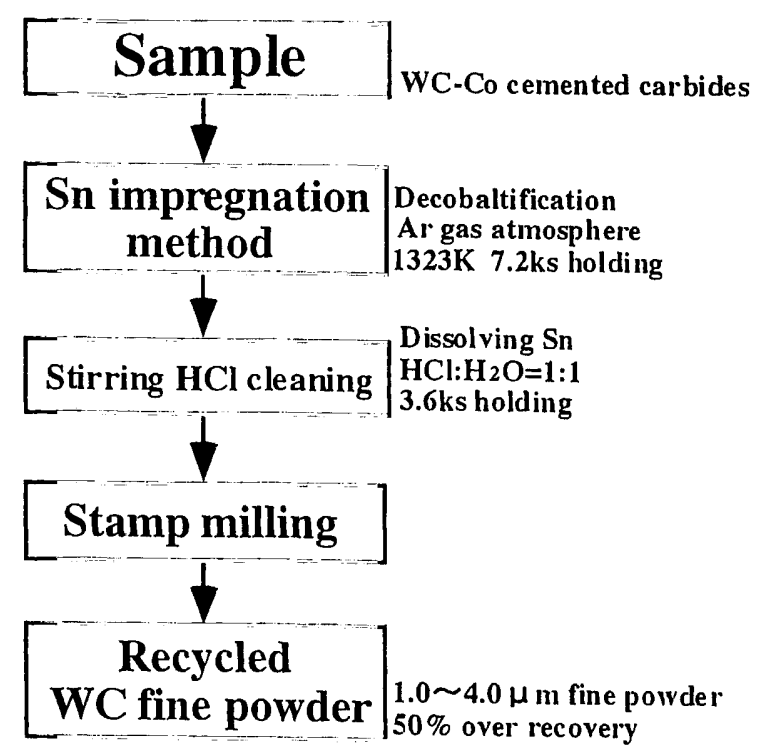

Fig.1 Recycling process of WC fine powder contained in cemented carbides. 
ることで, $1 \sim 4 \mu \mathrm{m}$ 程度の微粉末を 50 〜 $60 \%$ も得られるこ とを報告した ${ }^{1)}$.この方法では, 分級の際, $-45 \mu \mathrm{m}$ 以上の粉 末は再度筧汼洗浄+物理的粉砕を繰り返すことにより, WC 微粉末の回収率を高めた.

一方, この得られたWC微粉末は, Co等を加えることによ り，リサイクル超硬合金となり，完全な超硬合金のリサイク ルプロセスになる.本研究では得られたリサイクル微粉末を 用いて，市販のCo及び C (黒鉛で添加) との混合，圧縮成形 及び焼結加工を行い, 得られたリサイクル超硬合金の諸物性 を市販合金と比較し, 種々の問題点の解明とリサイクル合金 の開発を試みた。

\section{2 実験方法}

原料粉末としては俶サンアロイ製の超硬合金(DA50)を $\mathrm{Sn}$ 含浸法にて得られたリサイクルWC微粉末，比較のため用い た市販のWC粉末 (豊島製作所製, 平均粒径 $1 \mu \mathrm{m}$, 純度 $99 \%$ 以上)及びバイダーとして用いた市販の Co o粉末 (同上製, 平 均粒径 1 $2 \mu \mathrm{m}$, 純度 $99.9 \%$ 以上) を用い, 混合条件, 圧縮 時の成形挙動及び焼結挙動を検討し, 超硬合金のミクロ組織 及び各種物性值を比較検討した。

Fig.2はこの粉末を用いて，予備実験として，混合一成一焼 結した超硬合金の物性を検討した結果, 1,000 MPa以下と, か なり抗折力の低い值が出たため,その原因を究明するために， WC 微粉末における表面の酸素 $(\mathrm{O})$ 分析をEPMA で検討した ものである.還元処理無しの粉末はSn含漫処理一筧拌洗浄一 物理的粉碎により, 粉末表面に酸素が濃化しており,このま までは成形性及び焼結性が悪く, 当然,物性值も低かった.そ のため, リサイクル粉末は初めに水素の雾囲気下で還元処理 (1073 K-3.6 ks) を行った. その結果，(b) 図に示すように大 部分の酸素は取り除くことが出来たが, 完全に酸素を取り除 くことは困難であった.これは, 粉末の粒子同士が凝集して

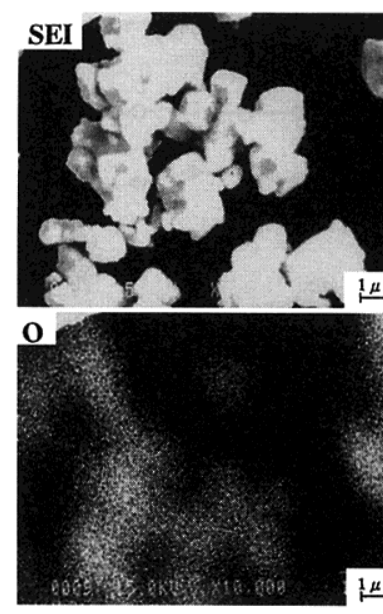

a)
Non-Reduction

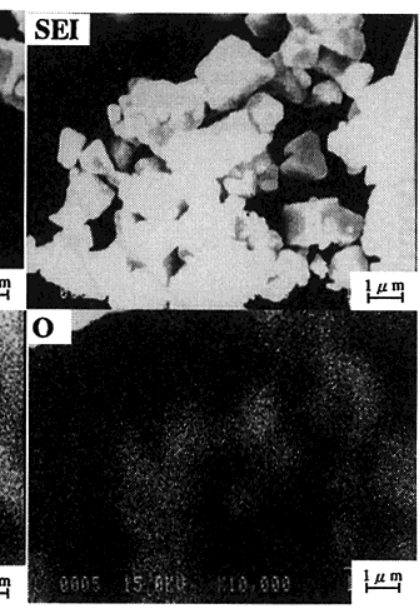

b)

Reduction(1073K-3.6ks)

Fig.2 Effect of reduction treatment obtained by recycled WC powders.
おり, 全ての表面で還元の効果が出にくかったことによるも のであった.

実験では，混合を自動乳鉢及び V型混合機2つを用い，そ れぞれの混合法が成形性及び焼結性に及ぼす影響を調べた。 なお，前述したように還元処理を行った結果，WC中のCが 不足し, $\eta$ 相 $\left.\left(\mathrm{W}_{3} \mathrm{Co}_{3} \mathrm{C}\right)^{3}\right)$ の生成も認められたため, 完全なWC 粉末とするため, 不足しているCを黒鉛で $0.2 \sim 0.3 \%$ 添加し， 脱炭の影響を極力取り除いた.つきに，成形では用途に応じ た金型を用い, 成形条件 $98 \sim 392 \mathrm{MPa}$, 成形時間 $5 \sim 30 \mathrm{~s}$ の 範囲で行なった.さらに, 焼結性については真空の雾囲気及 び水素雾囲気中で, 焼結温度 $1573 \sim 1673 \mathrm{~K}$ 及び保持時間 3.6 〜 14.4 ksの範囲で行った. 焼結密度はアルキメデス法を用い て正確に求めた。一方, 焼結体の諸物性を調べるため, 硬さ 試験及び抗折試験を行った. 初めに, 焼結体を平面研削盤で 加エし, 試料形状を整えた。硬さ試験はHRAで評価し, 抗折 力評価はJIS H 5501 に準拠して行った.

\section{3 実験結果及び考察}

Fig.3 (a) は市販WC粉末及び (b) は還元処理 $(1073 \mathrm{~K}-3.6 \mathrm{ks})$ まで行なったリサイクルWC粉末のSEM 写真である.市販の $\mathrm{WC}$ 粉末の形状は $1 \mu \mathrm{m}$ 程度の球状に近く, 粒子同士が凝集し,
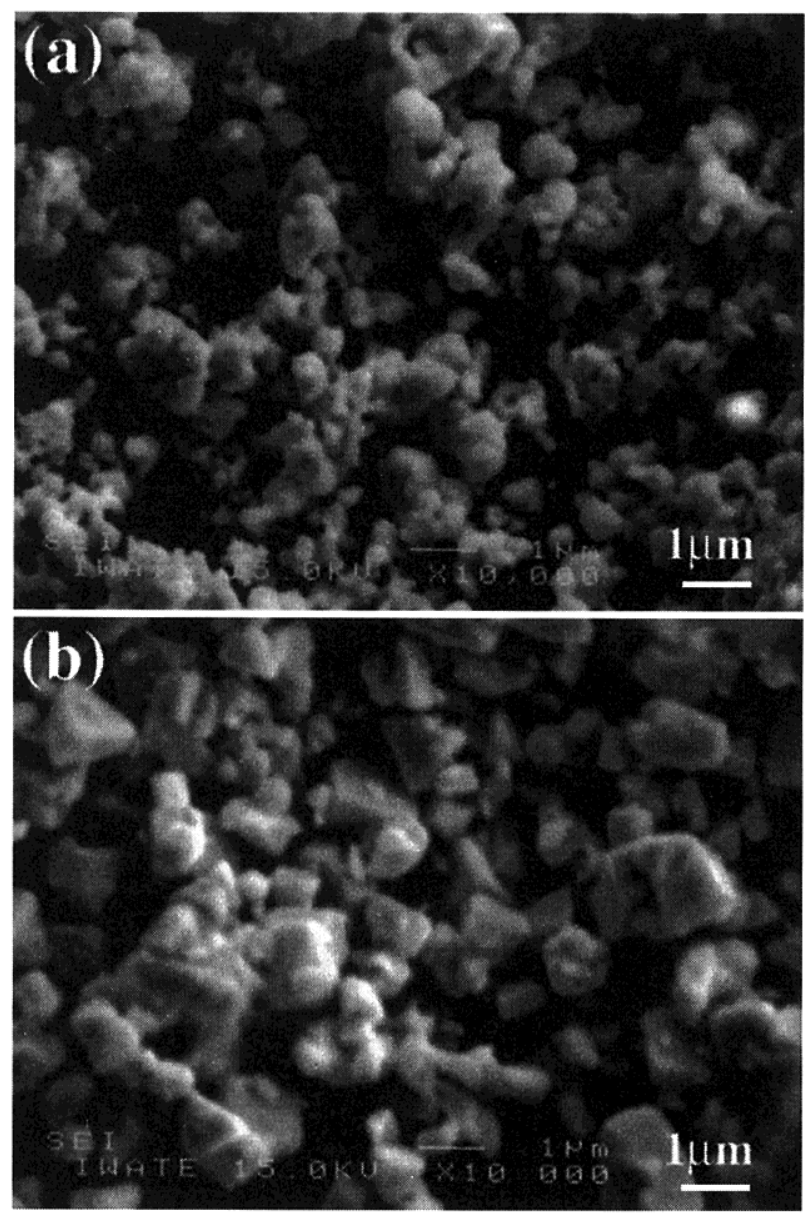

Fig.3 SEM micrographs of 2 types WC powder. (a) commercial powder (b) recycled powder 
数 $\mu \mathrm{m}$ の大きさになっていた。一方，リサイクルWC粉末の 形状は $1 \sim 3 \mu \mathrm{m}$ 程度の角状に近い粒子からなっていることか 判った.このような原料粉末形状の相違が後加工に及ぼす影 響を調べた。

Fig.4は両粉末を用い， 13 mass\% Co 及びC 分析結果から得 られた不足分の0.2〜0.3\%の黒鉛を添加した(リサイクルWC 粉末のみ)成形体の成形圧力と成形密度を示す.この結果, 混 合方法恃自動乳鉢でもV型混合機で作成しても大差なかった が, 市販粉で成形压力 $196 \mathrm{MPa}$ 以上, リサイクル粉では 245 MPa 以上で，成形体の側面に割れが観察された.いずれの粉 末でも成形圧力の增加により，成形密度は上昇していたが， 市販粉末では $147 \mathrm{MPa}$ の時成形密度が約 $43 \%, 392 \mathrm{MPa}$ の時 約 $49 \%$ となった.一方,リサイクル粉末は成形圧力が $147 \mathrm{MPa}$ の時,約 $54 \%$ と市販粉末より $11 \% も$ 高い成形密度か得られた。 このように,リサイクル粉末が大幅に成形密度が向上したの は, 炭素量調整のため添加した $0.2 \sim 0.3 \%$ の黒鉛粉が固体潤 滑材として働いたと考えられた4).

Fig.5は両成形体の焼結温度と焼結密度の関係を示す.混合 方法は自動乳鉢で行った。再生超硬合金成形体の焼結密度変 化は $1633 \mathrm{~K}$ までは焼結温度の上昇に伴って増加し，約 94 95\%の值が得られた. その後, 一定になる.この挙動は市販 成形体の焼結挙動と同様の傾向であった. 尚, $1573 \mathrm{~K} て ゙$ 市販 品に比べ再生品は約 $9 \%, 1603 \mathrm{~K}$ で約 $4 \%$ 低い值が得られた。 しかし，1633 K 以上ではその差は $1 \%$ 程度に減少した.この ことは原料粉末の形状の影響，すなわちリサイクル粉末が角 状の形態であることが影響していると考えられた。また， $1653 \mathrm{~K}$ 以上の市販成形体は基盤(イットリウム安定化ジルコ ニア‥YSZ)に溶着するという現象が見られた。

Fig.6は同様に両焼結品の焼結温度と硬さ(HRA)の関係を示 している.市販品及び再生焼結品とも焼結温度の上昇と共に 硬さは增加するが, $1633 \mathrm{~K}$ 以上では市販品は約 89 及び再生品 は 87.5 と若干低い值となった。この傾向は Fig.5に示した焼

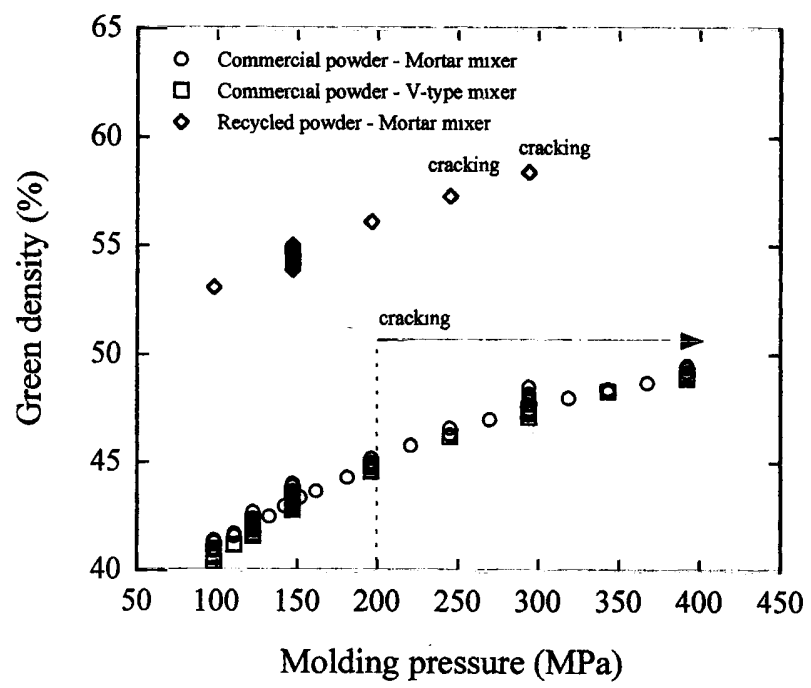

Fig.4 Relation between green density and molding pressure obtained by difference of commercial or recycled powders.
結密度の変化に非常によく対応しており,焼結が十分進んで いることが推察された。

Fig.7は硬さ (HRA)の変化について, (a) は焼結雾囲気の影 響, (b)は燒結時間の影響を示している. (a)では 13 及び $0.13 \mathrm{~Pa}$ まで変化させたが，焼結温度 1633Kでの值は Fig.6 と同様に 市販品が約HRA 89 及び再生品が約HRA 87.5 となり, 真空度 の影響はほとんどなかった。一方,(b)では焼結時間(3.6〜14.4 ks)が長くなるほど, 市販品はHRAが89.5から 86.5 に低下す るが, 再生品は焼結時間にほとんど依存せず, 約HRA 87.5で あった。この結果，焼結温度は $1633 \mathrm{~K}$ と工業化の実用温度 $1673 \mathrm{~K} よ り ， 40 \mathrm{~K}$ 低いが，ほぼJISを満足する硬さが得られれ ることが判明した。

Fig.8は今回用いた(划サンアロイ製の超硬合金(DA50)の受 入材と今回リサイクルで得られた再生超硬合金のミクロ組織

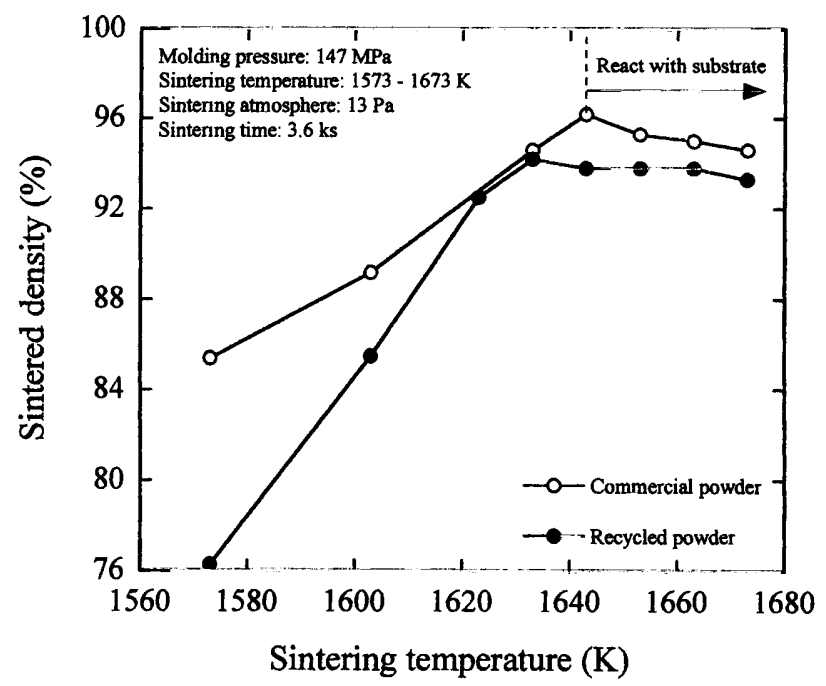

Fig.5 Relation between sintered density and sintering temperature obtained by difference of commercial or recycled powders.

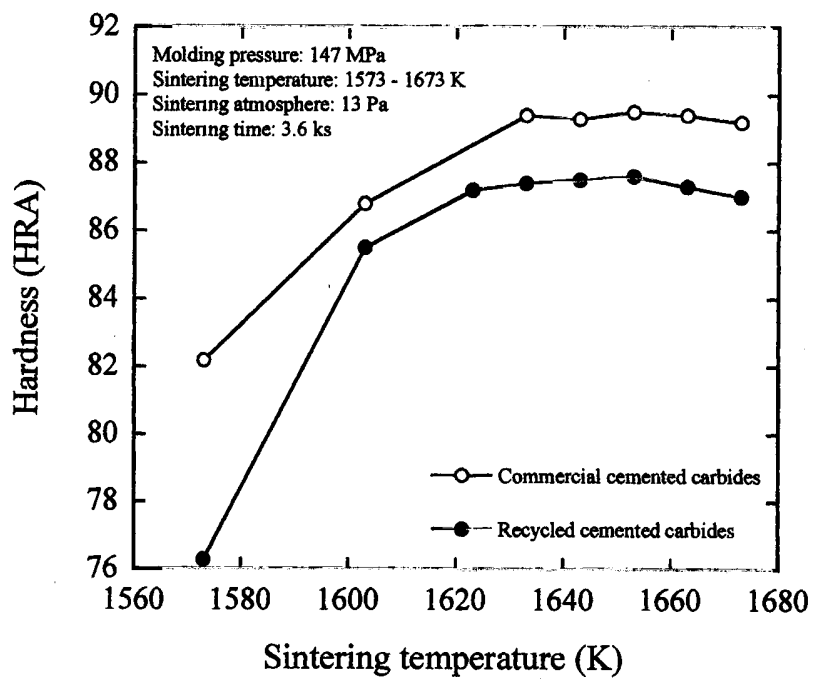

Fig.6 Relation between hardness and sintering temperature obtained by difference of commercial or recycled cemented carbides. 

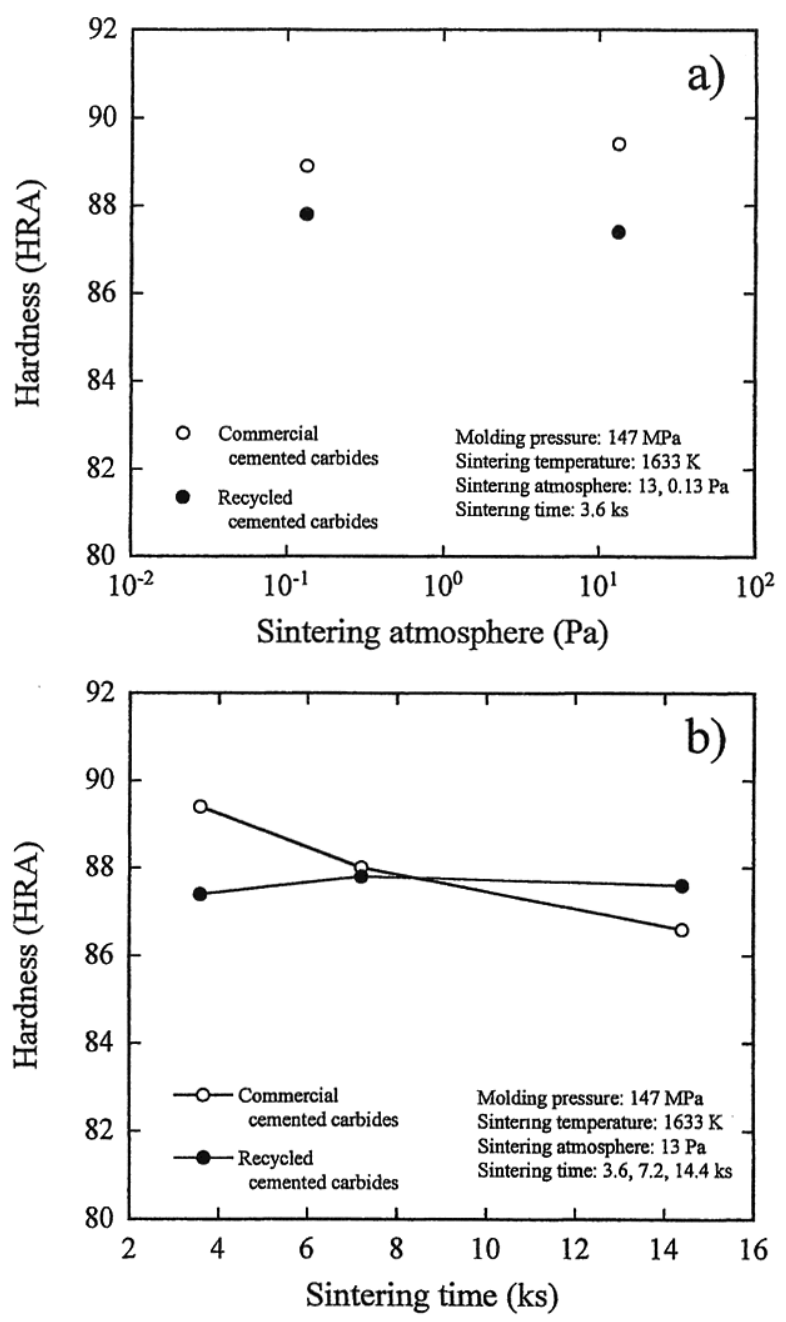

Fig.7 Effect of hardness on commercial or recycled cemented carbides. a) sintering atmosphere, b) sintering time.

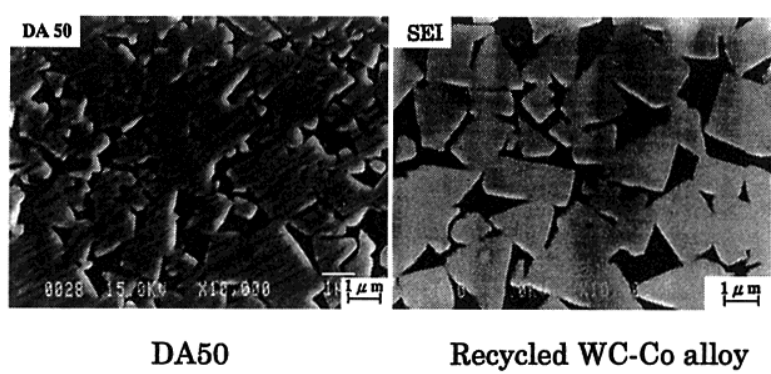

Fig.8 Comparison of SEM microstructures between commercial alloy (DA50) and recycled WC-Co alloy.
を示している.この結果,リサイクル粉は前述した粒径が,市 販品に比べて若干大きいため, 焼結密度及び硬さ (HRA)の データは Fig.5 及び Fig.6に示されたように若干低い結果と なった.しかし，ミクロ組織では大幅な相違はなく，機械的 特性などの低下がない物性值が得られることが期待された.

Table 1 は本実験で得られた再生超硬合金と市販のDA50の 各種物性值を比較したものである. 化学組成では, 再生超硬 合金で残留 $\mathrm{Sn} か ゙ 0.05 〜 0.07$ mass\% 認められたが, 密度及び 硬度はほぼ同一であった. 一方, 最も重要なデー夕である抗 折力は市販品で 3,038 3,136 MPa であり, 再生超硬合金は $2,700 \sim 2,820 \mathrm{MPa}$ と, 約 $90 \%$ の值を得た. しかし,この低下 の原因となる残留Snの完全除去が問題であり,市販品と同程 度の抗折力を得るためには, 課題として残った. なお, 再生 超硬合金でも JIS 規格は十分クリアし，実用上使用できる範 囲の材料が得られた。

Fig.9 は本研究のまとめを示したものである. すなわち, 廃 棄超硬合金から再生超硬合金のリサイクルプロセスについて 述べる. 実験では, 初めに $1323 \mathrm{~K}-7.2 \mathrm{ks}$ のSn浴に超硬合金を 入れて超硬合金中の Co と Sn を反応させた. Co 元素の Sn 含 浸処理後, 取り出した試料の超硬合金(WCと Co-Sn 化合物) について物理的な粉砕を行い, 可能な限り微細な粉末を得た.

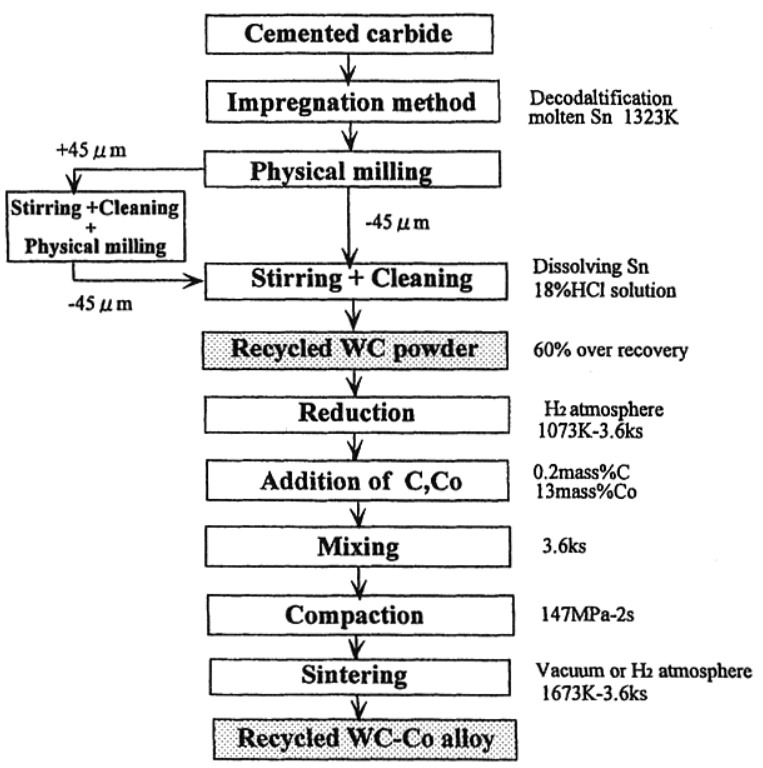

Fig.9 Flow chart of recycling process on disposal cemented carbides.

Table 1 Comparison of chemical composition and some properties between commercial alloy (DA50) and recycled WC-Co alloy.

\begin{tabular}{|c|c|c|c|c|c|c|c|}
\hline \multirow{2}{*}{ SAMPLE } & \multicolumn{4}{|c|}{$\begin{array}{l}\text { Chemical Composition } \\
\text { (mass\%) }\end{array}$} & \multirow{2}{*}{$\begin{array}{l}\text { Density } \\
\left(\mathrm{g} / \mathrm{cm}^{2}\right)\end{array}$} & \multirow{2}{*}{$\begin{array}{c}\text { Deflective } \\
\text { Strength } \\
(\mathrm{MPa})\end{array}$} & \multirow{2}{*}{$\begin{array}{l}\text { Hardness } \\
\text { (HRA) }\end{array}$} \\
\hline & $\mathrm{W}$ & $\mathrm{Co}$ & $\mathrm{C}$ & $\mathrm{Sn}$ & & & \\
\hline DA50 & 81.67 & 13.00 & 5.33 & - & 14.20 & $3038 \sim 3136$ & 87.6 \\
\hline $\begin{array}{l}\text { Recycled } \\
\text { WC-Co }\end{array}$ & 80.73 & $\begin{array}{c}13.54 \\
\sim \\
13.87\end{array}$ & 5.27 & $\begin{array}{c}0.05 \\
\sim \\
0.07\end{array}$ & 14.04 & $2700 \sim 2820$ & $87.8 \sim 88.6$ \\
\hline
\end{tabular}


すなわち, スタンプミル及びハンマーで破壊した後，自動乳 鉢またはボールミルで可能な限り微細化するよう粉砕した。 なお, 粉砕時間は条件に応じて変化させた $(3.6 〜 10.8 \mathrm{ks})$.さ らに，粉研後の擋汼洗浄法としてWC-Sn 及び $\gamma^{\prime}$ 相粉碎粒を $18 \mathrm{vol} \% \mathrm{HCl}\left(\mathrm{HCl}: \mathrm{H}_{2} \mathrm{O}=1: 1\right)$ 中で行った. $\mathrm{Sn}$ 及び $\mathrm{Sn}$ 化合物, 特に $\gamma^{\prime}$ 相は簡単に $\mathrm{HCl}$ に溶解する. 洗浄時間としては3.6〜 $10.8 \mathrm{ks}$ とした.この処理により得られたWC粒子は $-45 \mu \mathrm{m} ま$ で分級した. $+45 \mu \mathrm{m}$ の粒子は再び粉研+擋汼洗浄を繰り返し 行い,WC粒子の回収率の目標は $60 \%$ とした. 一方, 含漫処 理後の超硬試料は蛍光X線装置及びEPMAによる定量分析を 行った.さらに粉砕したWC粉末回収後にも重量・粒径の測 定, SEMによる観察と蛍光X線分析及びEPMAによる $\mathrm{Co}, \mathrm{Sn}$ の定量分析を行った。

このようにして得られた再生WC粉末は，含漫処理及び摚 汼洗浄等によりWC表面に付着した酸素を除去するため, 水 素による還元処理 $(1073 \mathrm{~K}-3.6 \mathrm{ks})$ を行った.この影響による 脱炭分 0.2 mass\% C を添加，さらに新たに 13 mass\% Co を添加 し， $3.6 \mathrm{ks}$ 自動乳鉢等で混合した。このWC-Co粉末は，その 後, $147 \mathrm{MPa}$ の圧力で成形され，各種試験片を作成した。焼 結は真空䨌囲気下で $1673 \mathrm{~K}-3.6 \mathrm{ks}$ の狫結条件で再生超硬合 金を得た。再生超硬合金は虽光X線分析とEPMAによる定量 分析, SEMによる観察, 硬度值及び抗折力測定を行い市販の DA50 との比較検討を行った結果, Sn が若干残留するが, JIS 規格に準抛する再生超硬合金が得られた。ささらにプレス用 金型を作成し，実機試験も行ったが良好な值が得られた。

\section{4 結 言}

超硬合金の積極的なリサイクルを考え，金型製作過程で発 生するブロック状の廃棄超硬合金を錫含浸法で脆化した合金 にし, 粉砕後WC粉末を得た. その後還元処理，混合，圧縮 成形及び焼結加工を行った. 得られた再生超硬合金を市販の 超硬合金と緒物性の比較, 問題点の解明を通じて種々検討し た結果，以下の結論を得た。

（1）錫含浸法で得られたWC微粉末 $(1 \sim 4 \mu \mathrm{m})$ は, 錫含漫, 摫 汼洗浄及び物理的粉砕の結果，WCに表面酸化が現われ，
焼結後の物性値に低下が認められた.そのため, WC 微粉 末は水素雾囲気で $1073 \mathrm{~K}-3.6 \mathrm{ks}$ の還元処理が必要であっ た。

(2) 還元処理後のリサイクルWC微粉末をCo及び黒鉛を添加 して圧粉体に成形すると，黒鉛が固体潤滑材として作用 し，市販粉末からの圧粉体より $10 \sim 12 \%$ も圧粉密度が高 くなることが判明した.

(3) 真空雾囲気下で $1673 \mathrm{~K}-3.6 \mathrm{ks}$ の焼結条件で処理すること により,再生超硬合金は錫が若干残留するが，抗折力が市 販品の約 90\%，硬度及び焼結密度共同程度の再生合金を 開発できた。

(4)これらの実験の結果, 錫含浸一物理的粉砕一穓汼洗浄で リサイクルWC微粉末が得られた.さらに, 置元処理一混 合 $(\mathrm{Co}, \mathrm{C})$ 一成形一焼結加工のわずか7工程でほぼ市販品 と同程度の再生超硬合金を作成可能であることがわかっ た.この開発された手法は,安価で省エネルギー技術でも あった.

\section{謝辞}

本研究を遂行するにあたり，終始研究協力頂きました，当 時岩手大学工学部材料物性工学科学生の三上珠美氏及び畑敏 弥氏に心より感謝申し上げます。

\section{文献}

1) M.Nakamura, M.Tagusari: "Recycling Technique of WC Fine Powder Contained in Cemented Carbides by Tin Impregnation Method", J. Jpn. Soc. Powder Powder Metallurgy, in contributing.

2) M.Nakamura: "Re-powdering Technique of Used Cemented Carbides Parts by Tin Impregnation Method", Jpn. Patent 2000072430.

3) K.Yoshida: "Cemented Carbides Tools", Nikkan Kogyo Press, (1982) 20-22.

4) Japan Powder Metallurgy Association: "Sintering Mechanical Parts-Planning and manufacturing-", Gijutsushoin, (1985)333. 